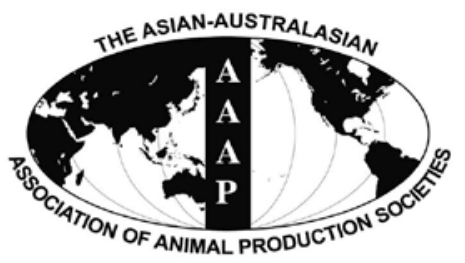

Asian-Aust. J. Anim. Sci.

Vol. 25, No. 1 : 86 - 91

January 2012

www.ajas.info

http://dx.doi.org/10.5713/ajas.2011.11249

\title{
Methane Production of Different Forages in In vitro Ruminal Fermentation
}

\author{
S. J. Meale, A. V. Chaves*, J. Baah ${ }^{1}$ and T. A. McAllister ${ }^{1}$ \\ The University of Sydney, Faculty of Veterinary Science, Sydney, NSW 2006, Australia \\ ${ }^{1}$ Agriculture and Agri-Food Canada, Lethbridge Research Centre, P. O. Box 3000 - Lethbridge, Alberta, Canada
}

\begin{abstract}
An in vitro rumen batch culture study was completed to compare effects of common grasses, leguminous shrubs and non-leguminous shrubs used for livestock grazing in Australia and Ghana on $\mathrm{CH}_{4}$ production and fermentation characteristics. Grass species included Andropodon gayanus, Brachiaria ruziziensis and Pennisetum purpureum. Leguminous shrub species included Cajanus cajan, Cratylia argentea, Gliricidia sepium, Leucaena leucocephala and Stylosanthes guianensis and non-leguminous shrub species included Annona senegalensis, Moringa oleifera, Securinega virosa and Vitellaria paradoxa. Leaves were harvested, dried at $55^{\circ} \mathrm{C}$ and ground through a $1 \mathrm{~mm}$ screen. Serum bottles containing $500 \mathrm{mg}$ of forage, modified McDougall's buffer and rumen fluid were incubated under anaerobic conditions at $39^{\circ} \mathrm{C}$ for $24 \mathrm{~h}$. Samples of each forage type were removed after $0,2,6,12$ and $24 \mathrm{~h}$ of incubation for determination of cumulative gas production. Methane production, ammonia concentration and proportions of VFA were measured at $24 \mathrm{~h}$. Concentration of aNDF (g/kg DM) ranged from 671 to 713 (grasses), 377 to 590 (leguminous shrubs) and 288 to 517 (non-leguminous shrubs). After $24 \mathrm{~h}$ of in vitro incubation, cumulative gas, $\mathrm{CH}_{4}$ production, ammonia concentration, proportion of propionate in VFA and IVDMD differed $(\mathrm{p}<0.05)$ within each forage type. B. ruziziensis and $G$. sepium produced the highest cumulative gas, IVDMD, total VFA, proportion of propionate in VFA and the lowest A:P ratios within their forage types. Consequently, these two species produced moderate $\mathrm{CH}_{4}$ emissions without compromising digestion. Grazing of these two species may be a strategy to reduce $\mathrm{CH}_{4}$ emissions however further assessment in in vivo trials and at different stages of maturity is recommended. (Key Words : In vitro, Chemical Composition, Forage Leaves, Methane)
\end{abstract}

\section{INTRODUCTION}

Methane emissions from ruminant livestock have increased five fold over the last century (Johnson et al., 2000) and now constitute $\sim 15 \%$ of global $\mathrm{CH}_{4}$ emissions (McAllister et al., 1996). In Australia, enteric $\mathrm{CH}_{4}$ emissions account for $10.5 \%$ of the national greenhouse gas emission (Grainger et al., 2008). Methane production also represents a loss of 2 to $12 \%$ of dietary energy in ruminants (Johnson and Johnson, 1995), this is especially the case in Australia with the consumption of high fibre pastures producing $\sim 1 \mathrm{t} \mathrm{CH} / \mathrm{t}$ of liveweight gain (Leng, 1993). However, improving forage quality (i.e. increasing dietary starch content) through the supplementation of alternative forages, such as leguminous and non-leguminous shrubs, has the potential to reduce $\mathrm{CH}_{4}$ emissions per $\mathrm{kg}$ animal

\footnotetext{
* Corresponding Author : A. V. Chaves. Tel: +61-2-9036-9312, Fax:+61-2-9351-3957, E-mail: alex.chaves@sydney.edu.au Received July 27, 2011; Accepted September 14, 2011
}

product as a result of increased diet digestibility and a shortened duration of feeding (Beauchemin et al., 2009). Dietary strategies such as this, have been successful in manipulating methanogenesis, at least in the short term, through either i) the direct inhibition of methanogens, ii) reducing the production of hydrogen in the rumen or iii) providing alternative sinks for the disposal of hydrogen (Beauchemin et al., 2009). For example, secondary plant compounds (e.g.: condensed tannins and saponins) have been shown to reduce enteric $\mathrm{CH}_{4}$ emissions through the direct inhibition of methanogens (Carulla et al., 2005). Similarly, the inclusion of high starch feedstuffs, favour the production of propionate and reduce ruminal $\mathrm{pH}$, thus inhibiting methanogen and protozoal growth (Boadi et al., 2004).

The objective of this study was to characterise common grasses, leguminous shrubs and non-leguminous shrubs used for livestock grazing in parts of Australia and Ghana based on the methanogenic activity of ruminal bacteria $\left(\mathrm{CH}_{4}\right.$ production at $\left.24 \mathrm{~h}\right)$ using batch culture in vitro 
fermentation and to identify species which produce favourable fermentation profiles.

\section{MATERIALS AND METHODS}

\section{Batch culture in vitro incubation}

Twelve forage species were examined using batch culture in vitro fermentation. Grass species were Andropodon gayanus, Brachiaria ruziziensis and Pennisetum purpureum. Leguminous shrub species consisted of Cajanus cajan, Cratylia argentea, Gliricidia sepium, Leucaena leucocephala and Stylosanthes guianensis and non-leguminous shrub species were Annona senegalensis, Moringa oleifera, Securinega virosa and Vitellaria paradoxa. The forages were collected from native pastures near the Savanna Agricultural Research Institute at Nyankpala in the Guinea Savanna zone of Northern Ghana $\left(9^{\circ} 54^{\prime} \mathrm{N}, 0^{\circ} 59^{\prime} \mathrm{W}\right)$. The location is characterized by a monomodal rainfall pattern with mean annual rainfall of $1,140 \mathrm{~mm}$. Leaf samples of all leguminous and nonleguminous shrubs, and grasses were re-growths and collected $\sim 60 \mathrm{~d}$ after the start of the rainy season. After harvest, leaves were dried at $55^{\circ} \mathrm{C}$ and ground through a 1 $\mathrm{mm}$ screen prior to in vitro incubation.

Rumen liquor was obtained from three ruminally fistulated lactating Holstein dairy cows $(617 \pm 8.9 \mathrm{~kg}$ body weight; $45 \pm 13.1 \mathrm{~d}$ in milk) fed a total mixed ration containing $180 \mathrm{~g}$ crude protein (CP)/kg DM and $330 \mathrm{~g}$ neutral detergent fibre (aNDF)/kg DM. Cows were cared for in accordance with guidelines of the Canadian Council on Animal Care (1993). Ruminal liquor was collected from the anterior dorsal, anterior ventral, medium ventral, posterior dorsal and posterior ventral locations within the rumen $2 \mathrm{~h}$ after the morning feeding. Pooled ruminal fluid (e.g.: from the three cows) was strained through 4 layers of cheesecloth into an insulated thermos and immediately transported to the laboratory. Strained ruminal fluid was continuously purged under $\mathrm{O}_{2}$-free $\mathrm{N}$ gas and kept at $39^{\circ} \mathrm{C}$ in a water bath prior to use in in vitro incubations. The liquor was used for inoculum of in vitro bottles within 20 min of collection.

In vitro incubations were in $50 \mathrm{ml}$ bottles fitted with rubber stoppers to prevent escape of fermentation gases (Wang et al., 2000). Bottles were placed in an incubator (Forma Scientific, model 39419-1, Marietta, OH, USA) with a capacity for 204 bottles. Incubator temperature was $39 \pm 0.5^{\circ} \mathrm{C}$ and bottles were affixed to a rotary shaker platform at 120 oscillations/min (Lab-Line Instruments Inc, Melrose Park, IL, USA). On the day before incubation, 0.5 g DM of each forage sample $(n=2)$ was weighed into each bottle ( $n=3$ for each treatment). On the day of incubation, bottles containing substrate were warmed to $39^{\circ} \mathrm{C}$ in the incubator for $60 \mathrm{~min}$, and gassed with $\mathrm{N}_{2}$ before adding 20 $\mathrm{ml}$ of a 3:1 mixture of buffer:rumen fluid saturated with $\mathrm{CO}_{2}$ with $0.5 \mathrm{ml}$ cysteine sulphide reducing agent (Wang et al., 2000). Bottles were capped and placed in the incubator at $39^{\circ} \mathrm{C}$. Three bottles containing inoculum only were also included at each time point as a blank control.

Gas samples were measured at 2, 6, 12 and $24 \mathrm{~h}$ of incubation. The procedure for sampling bottles was: 39 bottles ( 3 replicates $\times 12$ treatments +3 blanks) were removed from the incubator and gas production from each bottle was immediately determined using a water displacement apparatus (Fedorak and Hrudey, 1983). For $\mathrm{CH}_{4}$ determination, $20 \mathrm{ml}$ of headspace gas was collected from the bottles at $24 \mathrm{~h}$ by inserting a $20 \mathrm{ml}$ syringe through the septum and immediately transferring it into a $6.8 \mathrm{ml}$ evacuated exetainer (Labco Ltd., High Wycombe, England) thus ensuring a positive pressure in the containers. A $3 \mathrm{ml}$ subsample of gas was removed from each exetainer and analyzed for $\mathrm{CH}_{4}$ by gas chromatography as described by Chaves et al. (2006). Methane was expressed as $\mathrm{mg} \mathrm{CH}_{4} / \mathrm{g}$ digested $\mathrm{DM}$ and total net gas production in $\mathrm{ml} / \mathrm{g} \mathrm{DM}$ incubated (Chaves et al., 2006).

At 24 h of incubation, incubation bottles $(n=3)$ of each forage were withdrawn from the incubator and put in ice to stop fermentation, and then processed for determination of volatile fatty acids (VFA), ammonia and in vitro DM disappearance (IVDMD) as described by Wang et al. (2008).

Determination ammonia : A sub-sample $(1.5 \mathrm{ml})$ of the media culture from each bottle were transferred to $2 \mathrm{ml}$ micro-centrifuge tubes containing $150 \mu \mathrm{l}$ trichloroacetic acid (TCA; 0.25\%; w/v) and centrifuge at 14,000 $\times \mathrm{g}$ for ten minutes (Spectrafuse 16M, National Labnet Co., Edison, NJ, USA) to precipitate particulate matter. The supernatant was transferred into $2 \mathrm{ml}$ microcentrifuge tubes and stored frozen at $-20^{\circ} \mathrm{C}$ until it was analyzed for ammonia-N by phenyl-hypochlorite reaction (Weatherburn, 1967). Blank 0 $\mathrm{h}$ samples were also used to analyze for ammonia and to calculate the net ammonia-N production.

Determination of volatile fatty acids (VFA) : An additional sub-sample $(1.5 \mathrm{ml})$ of the culture in each bottle was also removed and $150 \mu \mathrm{l}$ of metaphosphoric acid (20\%; $\mathrm{w} / \mathrm{v}$ ) was added before the samples were centrifuged in the same manner as the ammonia analysis. The supernatant was stored frozen at $-20^{\circ} \mathrm{C}$ and later analyse for VFA concentrations by high-performance liquid chromatography (HPLC; SHIMADZU model SPD-10A VP with an Ultra UV Detector waves lengths of $210 \mathrm{~nm}$ ) equipped with a SCR-101 H silica $30 \mathrm{~cm} \times 7.9 \mathrm{~mm} \times 1 \mu \mathrm{m}$ capillary column. Blank $0 \mathrm{~h}$ samples were also analyzed for VFA and to determine the net total VFA production.

In vitro DM disappearance : Following the collection of the supernatants samples for ammonia and VFA analyses after $24 \mathrm{~h}$ of incubation, the contents of the incubation bottles were transferred into preweighed $50 \mathrm{ml}$ centrifuge 
tubes, rinsed with distilled water into the tubes, and centrifuged twice at $500 \times \mathrm{g}$ for $10 \mathrm{~min}$ at $4^{\circ} \mathrm{C}$. The supernatant was discarded, and the precipitate dried at $55^{\circ} \mathrm{C}$ for $48 \mathrm{~h}$ and weighed to estimate the in vitro DM disappearance (IVDMD).

\section{Chemical composition}

Duplicate samples of each forage were analysed for neutral detergent fibre (aNDF) with a heat stable $\alpha$-amylase and sodium sulphite (Mertens, 2002) and for acid detergent fibre (ADF) using method 973.18 (AOAC, 1990). Concentrations of aNDF and ADF are expressed inclusive of residual ash. Lignin (sa) was completed on ADF residues by solubilisation with sulphuric acid (Robertson and Van Soest, 1981). Ash was determined after $2 \mathrm{~h}$ of oxidation at $600^{\circ} \mathrm{C}$ in a muffle furnace using method 942 (AOAC, 1990). Samples were re-ground using a ball grinder (Mixer Mill MM2000, Retsch, Haan, Germany) for determination of $\mathrm{N}$ by flash combustion with gas chromatography and thermal conductivity detection (Carlo Erba Instruments, Milan, Italy).

\section{Statistical analyses and calculation}

Methane production was calculated as:

$$
\begin{aligned}
\text { g } \mathrm{CH}_{4} / \text { g digested DM } \\
=\left(\left(\text { gas production } 24 \mathrm{~h} \times\left(\left[\mathrm{CH}_{424 \mathrm{~h}}\right]\right)\right.\right. \\
\left.\left.\quad \text {-gas produced blank } 24 \mathrm{~h} \times\left[\mathrm{CH}_{4} \text { blank }_{24 \mathrm{~h}}\right]\right)\right) \\
\quad / \text { g digested DM }
\end{aligned}
$$

according to Chaves et al. (2006).

In vitro data were analyzed as a completely randomized design using the MIXED procedure of SAS (2011). Means within forage family (e.g., leguminous shrubs, nonleguminous shrubs or grasses) were compared using the least squares mean linear hypothesis test included as fixed terms. Results are reported as least squares means ( $\pm \mathrm{SEM}$ ). Significance was declared at $\mathrm{p} \leq 0.05$.

\section{RESULTS AND DISCUSSION}

Concentrations of crude protein (CP; $\mathrm{g} \mathrm{kg}^{-1} \mathrm{DM}$ ) and NDF ( $\mathrm{g} \mathrm{kg}^{-1} \mathrm{DM}$ ) in $P$. purpureum, G. sepium, and $M$. oleifera are comparable to previously reported values of 96 and 709 (Nogueira Filho et al., 2000); 92 and 421 (Abdulrazak et al., 1997) and 214 and 333 (Njidda and Nasiru, 2010), respectively (Table 1). Dietary crude protein and NDF concentrations influence the amount of substrate organic matter (OM) fermented and the short chain fatty acids that are produced (Njidda and Nasiru, 2010). Crude protein concentrations below the threshold of $70 \mathrm{~g} \mathrm{CP} \mathrm{kg}^{-1}$ $\mathrm{DM}$, restrict microbial activity due to a lack of nitrogen (Hariadi and Santoso, 2010). However, protein levels above this threshold, as seen in this study, are considered to enhance microbial multiplication in the rumen, thus improving fermentation (Njidda and Nasiru, 2010). Similarly, ammonia accumulation varied $(\mathrm{p}<0.05)$ within legume and shrub species, yet remained above the threshold

\begin{tabular}{|c|c|c|c|c|c|}
\hline Species & $\mathrm{CP}$ & aNDF & $\mathrm{ADF}$ & Lignin (sa) & Ash \\
\hline \multicolumn{6}{|l|}{ Leguminous shrubs } \\
\hline Cajanus cajan & 199 & 478 & 387 & 173 & 61 \\
\hline Cratylia argentea & 204 & 532 & 344 & 186 & 109 \\
\hline Gliricidia sepium & 236 & 427 & 311 & 125 & 71 \\
\hline Leucaena leucocephala & 301 & 377 & 289 & 95 & 81 \\
\hline Stylosanthes guianensis & 112 & 590 & 472 & 133 & 78 \\
\hline SD & 68.4 & 83.9 & 72.3 & 37.0 & 17.9 \\
\hline \multicolumn{6}{|l|}{ Non-leguminous shrubs } \\
\hline Annona senegalensis & 99 & 517 & 428 & 270 & 53 \\
\hline Moringa oleifera & 249 & 288 & 175 & 53 & 73 \\
\hline Securinega virosa & 170 & 307 & 263 & 87 & 65 \\
\hline Vitellaria paradoxa & 89 & 355 & 451 & 298 & 57 \\
\hline SD & 64.4 & 79.8 & 71.3 & 39.1 & 16.9 \\
\hline \multicolumn{6}{|l|}{ Grasses } \\
\hline Andropodon gayanus & 72 & 694 & 406 & 82 & 59 \\
\hline Brachiaria ruziziensis & 87 & 671 & 387 & 64 & 84 \\
\hline Pennisetum purpureum & 87 & 713 & 395 & 56 & 74 \\
\hline SD & 8.2 & 20.1 & 10.0 & 15.1 & 11.3 \\
\hline
\end{tabular}
value for both maximum microbial growth (Satter and Slyter, 1974) and fibre digestion (Hariadi and Santoso,

Table 1. Chemical composition of forage species expressed in $\mathrm{g} / \mathrm{kg} \mathrm{DM}$ ) used in the study

$\mathrm{DM}$ = Dry matter; $\mathrm{CP}$ = Crude protein; aNDF = Neutral detergent fibre; $\mathrm{ADF}$ = Acid detergent fibre. 
2010). This suggests that CP concentrations did not impede gas production or forage digestibility.

In vitro DMD and cumulative gas production $(\mathrm{ml} / \mathrm{g}$ $\mathrm{DM})$ also differed $(\mathrm{p}<0.05)$ within forage type in the current study. B. ruziziensis, G. sepium and M. oleifera produced the highest $(\mathrm{p}<0.05)$ cumulative gas and had the highest IVDMD within the grasses, leguminous and nonleguminous shrubs, respectively (Table 2) indicating that these species are highly fermentable. It is widely accepted that feedstuffs which have higher gas production and IVDMD tend to have higher $\mathrm{CH}_{4}$ production per gram DM incubated (Durmic et al., 2010; Njidda and Nasiru, 2010; Jayanegara et al., 2011). This trend was evident in nonleguminous shrub species, in addition to $P$. purpureum and S. guianensis (data not presented). This relationship is suggested to be a reflection of feed digestibility (Demeyer and Van Nevel, 1975; Holtshausen et al., 2009), in particular NDF concentration (Doane et al., 1997). Increasing cell wall content (i.e. NDF and ADF) is considered to suppress microbial activity through a reduction in the availability of rapidly fermented carbohydrates (Wilson and Hatfield, 1997). This is turn, is negatively correlated with gas production (Njidda and Nasiru, 2010). Similarly, in in vivo trials increasing fibre content is considered to reduce forage intake, ruminal residence time (Beauchemin et al., 2009; Archimède et al.,
2011) and fermentability (Wilson and Mertens, 1995) resulting in an increase in $\mathrm{CH}_{4}$ production per unit of $\mathrm{OM}$ digested (McAllister et al., 1996; Valenciaga et al., 2009).

In the current study, several forage species were able to favourably modulate rumen fermentation to produce $\mathrm{CH}_{4}$ concentrations lower than expected when considering their cumulative gas production and IVDMD. The most notable of which, G. sepium and B. ruziziensis, produced moderate amounts of $\mathrm{CH}_{4}$ compared with other species in their forage type, despite having the highest cumulative gas production, IVDMD and total VFA production. A strong positive relationship was observed between IVDMD and total VFA production, with total VFA production the greatest in species with high IVDMD, as would be expected. Interestingly, both $G$. sepium and B. ruziziensis, produced the highest proportion of propionate, and lowest acetate:propionate ratios, within their forage types.

Generally, the type of carbohydrate present in the forage is thought to dictate $\mathrm{CH}_{4}$ production via shifts in the ruminal microbial population (Johnson and Johnson, 1995). High soluble carbohydrate content is suggested to promote the production of propionate in the rumen, lower ruminal $\mathrm{pH}$ and inhibit methanogen growth thereby reducing $\mathrm{CH}_{4}$ production per unit of OM fermented (Van Kessel and Russell, 1996). Boadi and Wittenberg (2002) found $\mathrm{CH}_{4}$ production ( $\mathrm{L} \mathrm{CH}_{4} / \mathrm{kg}$ digestible $\mathrm{OM}$ intake) was $25 \%$

Table 2. Cumulative gas and methane production, ammonia accumulation, concentration and proportions of volatile fatty acids (VFA) and in vitro dry matter (DM) disappearance (IVDMD) of $24 \mathrm{~h}$ in vitro ruminal fermentation of different forage species

\begin{tabular}{|c|c|c|c|c|c|c|c|c|c|c|}
\hline & \multirow{2}{*}{$\begin{array}{c}\text { Gas ml/g } \\
\text { DM }\end{array}$} & \multirow{2}{*}{$\begin{array}{c}\text { Methane } \\
\text { mg/g } \\
\text { digested } \\
\text { DM }\end{array}$} & \multirow{2}{*}{$\begin{array}{c}\text { Ammonia, } \\
\mathrm{mM}\end{array}$} & \multicolumn{4}{|c|}{$\begin{array}{l}\mathrm{mol} / 100 \mathrm{~mol} \text { of total volatile fatty acids } \\
\text { (VFA) }\end{array}$} & \multirow{2}{*}{ A:P } & \multirow{2}{*}{$\begin{array}{l}\text { Total } \\
\text { VFA } \\
\mathrm{mM}\end{array}$} & \multirow{2}{*}{$\begin{array}{l}\text { IVDMD } \\
\text { g/kg DM }\end{array}$} \\
\hline & & & & $\begin{array}{l}\text { Acetate } \\
\text { (A) }\end{array}$ & $\begin{array}{l}\text { Propionate } \\
\text { (P) }\end{array}$ & Butyrate & $\begin{array}{l}\text { Minor } \\
\text { VFA }\end{array}$ & & & \\
\hline \multicolumn{11}{|l|}{ Leguminous shrubs } \\
\hline Cajanus cajan & $113.7^{c}$ & $9.6^{a b}$ & $22.5^{a}$ & $66.0^{b}$ & $19.3^{d}$ & $9.1^{a}$ & $5.5^{b}$ & $3.41^{b}$ & $73.2^{b}$ & $246^{d}$ \\
\hline Cratylia argentea & $125.1^{b}$ & $11.1^{a}$ & $1.1^{c}$ & $63.6^{c}$ & $20.7^{b}$ & $9.2^{a}$ & $6.5^{a}$ & $3.07^{c}$ & $75.2^{b}$ & $336^{c}$ \\
\hline Gliricidia sepium & $148.5^{a}$ & $8.0^{b c}$ & $-4.4^{d}$ & $66.2^{b}$ & $21.7^{a}$ & $6.9^{c}$ & $5.2^{b c}$ & $3.05^{c}$ & $97.2^{a}$ & $404^{a}$ \\
\hline Leucaena leucocephala & $126.8^{b}$ & $7.3^{c}$ & $17.4^{b}$ & $67.0^{b}$ & $20.0^{c}$ & $8.2^{b}$ & $4.8^{c}$ & $3.34^{b}$ & $79.8^{b}$ & $376^{a b}$ \\
\hline Stylosanthes guianensis & $128.8^{b}$ & $8.0^{b c}$ & $0.8^{c}$ & $68.7^{a}$ & $18.0^{e}$ & $8.2^{b}$ & $5.1^{b c}$ & $3.82^{a}$ & $81.7^{b}$ & $348^{b c}$ \\
\hline SEM & 1.48 & 0.53 & 0.89 & 0.49 & 0.16 & 0.19 & 0.19 & 0.047 & 3.81 & 12.8 \\
\hline \multicolumn{11}{|l|}{ Non-leguminous shrubs } \\
\hline Annona senegalensis & $94.5^{b}$ & $2.8^{c}$ & $14.3^{a}$ & $68.0^{a b}$ & $19.9^{a b}$ & $8.7^{c}$ & $3.3^{b c}$ & $3.41^{a b}$ & $68.7^{b}$ & $257^{c}$ \\
\hline Moringa oleifera & $187^{a}$ & $6.4^{a}$ & $0.4^{b}$ & $61.2^{c}$ & $20.7^{a b}$ & $12.7^{a}$ & $5.4^{a}$ & $2.95^{b}$ & $102.4^{a}$ & $540^{a}$ \\
\hline Securinega virosa & $101.4^{b}$ & $4.4^{b}$ & $0.9^{b}$ & $69.1^{a}$ & $16.5^{b}$ & $10.5^{b}$ & $3.9^{b}$ & $4.19^{a}$ & $58.9^{c}$ & $328^{b}$ \\
\hline Vitellaria paradoxa & $28.1^{c}$ & $0.4^{d}$ & $2.2^{b}$ & $62.7^{b c}$ & $24.2^{a}$ & $10.7^{b}$ & $2.5^{c}$ & $2.59^{b}$ & $18.4^{d}$ & $82^{d}$ \\
\hline SEM & 2.93 & 0.34 & 1.5 & 1.78 & 1.56 & 0.32 & 0.31 & 0.28 & 2.05 & 7.6 \\
\hline \multicolumn{11}{|l|}{ Grasses } \\
\hline Andropodon gayanus & $116.7^{c}$ & $15.6^{a}$ & 6.3 & 66.1 & $20.4^{b}$ & 9.4 & $4.2^{a}$ & $3.24^{a}$ & $86.8^{c}$ & $278^{c}$ \\
\hline Brachiaria ruziziensis & $143.4^{a}$ & $12.1^{b}$ & 10.6 & 64.8 & $22.6^{a}$ & 8.8 & $3.7^{b}$ & $2.87^{b}$ & $105.4^{a}$ & $379^{a}$ \\
\hline Pennisetum purpureum & $131.2^{b}$ & $11.6^{b}$ & 9.2 & 65.8 & $20.9^{b}$ & 9.2 & $4.0^{a}$ & $3.14^{a}$ & $95.9^{b}$ & $342^{b}$ \\
\hline SEM & 2.36 & 0.43 & 1.88 & 0.45 & 0.24 & 0.17 & 0.09 & 0.051 & 2.2 & 5.6 \\
\hline
\end{tabular}

Minor VFA = Iso-butyrate+iso-valerate+valerate+caproic acids.

${ }_{a, b, c, d}$ Least square means with different superscripts differ $\mathrm{p}<0.05$ within forage family (e.g., leguminous shrubs, non-leguminous shrubs or grasses). 
higher for low versus medium or high nutritional quality diets in a feeding study where intake was restricted to $2 \%$ of body weight. Lower $\mathrm{CH}_{4}$ losses with the high quality diet were expected as the lower fibre content shifted fermentation towards production of propionate. Chaves et al. (2006) demonstrated that diet quality affected $\mathrm{CH}_{4}$ production in an in vitro study where low concentrations of non-fibrous carbohydrates in both legumes (e.g., alfalfa) and grasses contributed to a low IVDMD and consequently high $\mathrm{CH}_{4}$ production per gram digested DM. Similarly, Boadi et al. (2002) showed that steers grazing early season pasture produced up to $45 \%$ less $\mathrm{CH}_{4}$ than those grazing in the mid and late season. However, in the current study, no correlation between NDF concentration and $\mathrm{CH}_{4}$ production was observed.

The presence of plant secondary metabolites (e.g. condensed tannins and saponins) may account for this, although, their presence was not examined in the current study. Tannins, common in tropical legumes (Waghorn, 2008), have been shown to reduce $\mathrm{CH}_{4}$ production by reducing fibre digestion (Tiemann et al., 2008); binding with proteins thus reducing degradation of the plant protein in the rumen and through the direct inhibition of the growth of methanogens (Tavendale et al., 2005). A study by Pinares-Patino et al. (2003) reported a reduction in $\mathrm{CH}_{4}$ emissions from grazing sheep, from $8 \%$ GEI to 3\% GEI, following consumption of the tannin rich forage, Lotus corniculatus. Similarly, Carulla et al. (2005) found that an extract of Acacia mearnsii (61.5\% CT) reduced $\mathrm{CH}_{4}$ emissions by $12 \%$ without decreasing fibre digestibility.

G. sepium and $B$. ruziziensis, were able to successfully modulate rumen fermentation characteristics, such that moderate $\mathrm{CH}_{4}$ emissions were produced without compromising forage digestion. Consequently, grazing of these two species may be a strategy to reduce $\mathrm{CH}_{4}$ emissions in Australia. However, as our forages were examined at only one stage of maturity, any effects of NDF concentration on $\mathrm{CH}_{4}$ production were not realised, as such there is a need for further assessment of fermentation characteristics of these species at various stages of maturity. Similarly, the relative scarcity of data on $\mathrm{CH}_{4}$ production from in vivo trials, where ruminants are fed tropical forages, suggests a need for additional studies.

\section{REFERENCES}

Archimède, H., M. Eugène, C. Marie Magdeleine, M. Boval, C. Martin, D. P. Morgavi, P. Lecomte and M. Doreau. 2011. Comparison of methane production between C3 and C4 grasses and legumes. Anim. Feed Sci. Technol. 166:59-64.

Association of Official Analytical Chemists (AOAC). 1990. Association of Official Methods of Analysis. AOAC, Arlington, VA, USA.
Beauchemin, K. A., T. A. McAllister and S. M. McGinn. 2009. Dietary mitigation of enteric methane from cattle. CAB Reviews: Perspectives in Agriculture, Veterinary Science, Nutrition and Natural Resources. 4:1-18.

Boadi, D., C. Benchaar, J. Chiquette and D. Masse. 2004. Mitigation strategies to reduce enteric methane emissions from dairy cows: Update review. Can. J. Anim. Sci. 84:319-335.

Boadi, D. A. and K. M. Wittenberg. 2002. Methane production from dairy and beef heifers fed forages differing in nutrient density using the sulphur hexafluoride (SF6) tracer gas technique. Can. J. Anim. Sci. 82:201-206.

Canadian Council on Animal Care. 1993. Guide to the care and use of experimental animals. CCAC, Ottawa, ON, Canada.

Carulla, J. E., M. Kreuzer, A. Machmuller and H. D. Hess. 2005. Supplementation of Acacia mearnsii tannins decreases methanogenesis and urinary nitrogen in forage-fed sheep. Aust. J. Agric. Res. 56:961-970.

Chaves, A. V., L. C. Thompson, A. D. Iwaasa, S. L. Scott, M. E. Olson, C. Benchaar, D. M. Veira and T. A. McAllister. 2006. Effect of pasture type (alfalfa vs. grass) on methane and carbon dioxide production by yearling beef heifers. Can. J Anim. Sci. 86:409-418.

Demeyer, D. I. and C. J. Van Nevel. 1975. Methanogenesis, an integrated part of carbohydrate fermentation, and its control. In: Digestion and Metabolism in the Ruminant (Ed. I. W. Mcdonald and A. C. I. Warner). The University of New England Publishing Unit, Armidale, NSW, Australia. pp. 366382.

Doane, P. H, P. Schofield and A. N. Pell. 1997. Neutral detergent fibre disappearance and gas and volatile fatty production during the in vitro fermentation of six forages. J. Anim. Sci. 75:3342-3352.

Durmic, Z., P. Hutton, D. K. Revell, J. Emms, S. Hughes and P. E. Vercoe. 2010. In vitro fermentative traits of Australian woody perennial plant species that may be considered as potential sources of feed for grazing ruminants. Anim. Feed Sci. Technol. 160:98-109.

Fedorak, P. M. and S. E. Hrudey. 1983. A simple apparatus for measuring gas production by methanogenic cultures in serum bottles. Environ.Technol. Lett. 4:425-432.

Grainger, C., T. Clarke, K. A. Beauchemin, S. M. McGinn and R. J. Eckard. 2008. Supplementation with whole cottonseed reduces methane emissions and can profitably increase milk production of dairy cows offered a forage and cereal grain diet. Aust. J. Exp. Agric. 48:73-76.

Hariadi, B. T. and B. Santoso. 2010. Evaluation of tropical plants containing tannin on in vitro methanogenesis and fermentation parameters using rumen fluid. J. Sci. Food Agric. 90:456-461.

Holtshausen, L., A. V. Chaves, K. A. Beauchemin, S. M. McGinn, T. A. McAllister, P. R. Cheeke and C. Benchaar. 2009. Feeding saponin-containing Yucca schidigera and Quillaja saponaria to decrease enteric methane production in dairy cows. J. Dairy Sci. 92:2809-2821.

Jayanegara, A., E. Wina, C. R. Soliva, S. Marquardt, M. Kreuzer and F. Leiber. 2011. Dependence of forage quality and methanogenic potential of tropical plants on their phenolic fractions as determined by principal component analysis. Anim. Feed Sci. Technol. 163:231-243. 
Johnson, D. E., K. A. Johnson, G. M. Ward and M. E. Branine. 2000. Ruminants and other animals. In: Atmospheric methane: Its role in the global environment (Ed. M. A. K. Kakil). Springer-Verlag, Berlin, Germany. pp. 112-133.

Johnson, K. A. and D. E. Johnson. 1995. Methane emissions from cattle. J. Anim. Sci. 73:2483-2492.

Leng, R. A. 1993. Quantitative ruminant nutrition - a green science. Aust. J. Agric. Res. 44:363-380.

McAllister, T. A., E. K. Okine, G. W. Mathison and K. J. Cheng. 1996. Dietary, environmental and microbiological aspects of methane production in ruminants. Can. J. Anim. Sci. 76:231243.

Mertens, D. R. 2002. Gravimetric determination of amylasetreated neutral detergent fiber in feeds with refluxing in beakers or crucibles: collaborative study. J. Assoc. Off. Anal. Chem. Int. 85:1217-1240.

Njidda, A. A. and A. Nasiru. 2010. In vitro gas production and dry mater digestibility of tannin-containing forges of semi-arid region of north-eastern Nigeria. Pakistan J. Nutr. 9:60-66.

Pinares-Patino, C. S., M. J. Ulyatt, G. C. Waghorn, K. R. Lassey, T. N. Barry, C. W. Holmes and D. E. Johnson. 2003. Methane emission by alpaca and sheep fed on lucerne hay or grazed on pastures of perennial ryegrass/white clover or birdsfoot trefoil. J. Agric. Sci. 140:215-226.

Robertson, J. B. and P. J. Van Soest. 1981. The detergent system of analysis. p. 123-158. In: The Analysis of Dietary Fibre in Food (Ed. W. P. T. James and O. Theander). Marcel Dekker, New York, NY, USA. Chapter 9.

SAS Institute, Inc. 2011. SAS OnlineDoc ${ }^{\circledR}$ 9.1.3. SAS Institute Incorporation. Cary, NC, USA.
Satter, L. D. and L. L. Slyter. 1974. Effect of ammonia concentration on rumen microbial protein production in vitro. Br. J. Nutr. 199-208.

Tavendale, M. H., L. P. Meagher, D. Pacheco, N. Walker, G. T. Attwood and S. Sivakumaran. 2005. Methane production from in vitro rumen incubations with Lotus pedunculatus and Medicago sativa, and effects of extractable condensed tannin fractions on methanogenesis. Anim. Feed Sci. Technol. 123:403-419.

Valenciaga, D., B. Chongo, R. S. Herrera, V. Torres, A. Oramas and M. Herrera. 2009. Effect of regrowth age on in vitro dry matter digestibility of Pennisetum purpureum cv. CUBA CT115. Cuban J. Agric. Sci. 43:79-82.

VanKessel, J. A. S. and J. B. Russell. 1996. The effect of pH on ruminal methanogenesis. FEMS Microbiol. Ecol. 20:205-210.

Waghorn, G. 2008. Beneficial and detrimental effects of dietary condensed tannins for sustainable sheep and goat productionProgress and challenges. Anim. Feed Sci. Technol. 147:116139.

Wang, Y., T. A. McAllister, L. J. Yanke and P. R. Cheeke. 2000. Effect of steroidal saponin from Yucca schidigera extract on ruminal microbes. J. Appl. Microbiol. 88:887-896.

Wang, Y., Z. Xu, S. J. Bach and T. A. McAllister. 2008. Effects of phlorotannins from Ascophyllum nodosum (brown seaweed) on in vitro ruminal digestion of mixed forage or barley grain. Anim. Feed Sci. Technol. 145:375-395.

Weatherburn, M. W. 1967. Phenol-hypochlorite reaction for determination of ammonia. Anal. Chem. 39: 971-974.

Wilson, J. R. and D. R. Mertens. 1995. Cell wall accessibility and cell structure limitations to microbial digestion of forage. Crop. Sci. 35:251-259. 